\title{
Chemical Composition of Atmospheric Precipitation at Monitoring Sites in Pribaikalye (East Siberia, Russia)
}

\author{
Natalia Onishchuk, Tamara Khodzher, Olga Netsvetaeva \\ Limnological Institute, Siberian Branch of the Russian Academy of Sciences, Irkutsk, Russia \\ Email: onischuk@lin.irk.ru,khodzher@lin.irk.ru,r431@lin.irk.ru
}

How to cite this paper: Onishchuk, N., Khodzher, T. and Netsvetaeva, O. (2017) Chemical Composition of Atmospheric Precipitation at Monitoring Sites in Pribaikalye (East Siberia, Russia). American Journal of Climate Change, 6, 374-384. https://doi.org/10.4236/ajcc.2017.62019

Received: February 10, 2017

Accepted: June 17, 2017

Published: June 20, 2017

Copyright $(9) 2017$ by authors and Scientific Research Publishing Inc. This work is licensed under the Creative Commons Attribution International License (CC BY 4.0).

http://creativecommons.org/licenses/by/4.0/

(c) †) Open Access

\begin{abstract}
This work presents the results of five-year investigations (2010-2014) on the content of water-soluble fraction of heavy metals in atmospheric precipitation in Pribaikalye (Russia). The studies have been performed at the urban (Irkutsk) and rural (Listvyanka) sites within the EANET program (Monitoring of Acid Deposition in East Asia) since 2000. Precipitation was sampled during continuous monitoring. In warm period (May-October), atmospheric precipitation was collected by automatic "wet-only" samplers. In cold season, plastic containers were used for snow sampling. Maximal concentrations of the majority of elements were recorded at site Irkutsk, which is subject to higher anthropogenic impact. The exception was for $\mathrm{Pb}, \mathrm{Ni}$ and $\mathrm{Zn}$ characterized by higher acidity, whose content was higher at the rural site. Maximal concentrations of the majority of elements were recorded in spring during the driest period of the year and minimal in summer with the annual maximal amount of precipitation. Correlation analysis revealed high coefficient of interconnection $\mathrm{V}$ and $\mathrm{Mn}$ with major acid-forming anions $\mathrm{SO}_{4}^{2-}$ and $\mathrm{NO}_{3}^{-}$. Maximal correlation coefficient (0.98) was recorded for Co and $\mathrm{NO}_{3}^{-}$at site Listvyanka. There was no correlation between $\mathrm{pH}$ of atmospheric precipitation and concentrations of all heavy metals, except $\mathrm{Pb}$. The results obtained show higher level of pollution of atmospheric precipitation by heavy metals at monitoring sites in Pribaikalye compared to some European countries.
\end{abstract}

\section{Keywords}

Atmospheric Precipitation, Heavy Metals, pH, Pribaikalye, Major Anions, Seasonal Dynamics

\section{Introduction}

Global emissions of heavy metals into atmosphere from the main anthropogenic 
sources have been reviewed in [1] [2]. According to this and other investigations, almost all industrial productions, combustion of fossil fuel, transport and other human activities cause anthropogenic dispersion of elements in the environment [3] [4] [5] [6]. Fuel combustion pollutes atmosphere with $\mathrm{As}, \mathrm{Cr}, \mathrm{Cu}$, $\mathrm{Mn}, \mathrm{Ni}, \mathrm{Sb}, \mathrm{Se}, \mathrm{V}$, and $\mathrm{Zn}$; nonferrous metallurgy causes pollution of atmosphere with $\mathrm{Ag}, \mathrm{As}, \mathrm{Cd}, \mathrm{Cu}, \mathrm{Ni}, \mathrm{Pb}, \mathrm{Sb}$, and $\mathrm{Zn}$, and ferrous metallurgy with $\mathrm{Cd}, \mathrm{Fe}, \mathrm{Mn}$, $\mathrm{Ni}, \mathrm{Pb}$, and $\mathrm{V}$ [7] [8].

In Russia, data on emissions of heavy metals from the main sources are incomplete, as some enterprises control rather emissions of particulates than those of heavy metals. This is attributed to the fact that heavy metals concentrate on the surface of particulates emitted, and their decrease automatically reduces emission of heavy metals. In addition, the control of emission of particulates is less complicated and less laborious than the control of certain metals. In European countries, the composition of heavy metals in atmospheric precipitation and atmospheric aerosol is monitored continuously, annual reports on investigations at monitoring sites are published [9] [10] [11] [12]. In Russia, monitoring of heavy metals in atmospheric air and precipitation is performed only in certain areas, and there is no constant control of their concentrations in atmosphere [13] [14] [15].

The study of chemical composition of atmospheric precipitation helps estimate the level of atmosphere pollution. Precipitation is an integral indicator of airborne pollution as they capture and wash out the majority of impurities, including heavy metals, from the atmosphere. Many of them are highly toxic [16] [17] [18] [19].

The aims of this work were to estimate quantitatively the content of heavy metals in atmospheric precipitation at monitoring sites in Pribaikalye, to study the mechanisms of them within year distribution and to reveal correlation between heavy metals and major anions.

\section{Materials and Methods}

Chemical composition of atmospheric precipitation was studied at monitoring sites-Irkutsk $\left(52.3^{\circ} \mathrm{N}, 104.4^{\circ} \mathrm{E}\right)$ and Listvyanka $\left(51.9^{\circ} \mathrm{N}, 104.7^{\circ} \mathrm{E}\right)$. Site Irkutsk is the largest industrial center in the south of East Siberia with the population of about 600,000 people. Site Listvyanka is a rural site located $70 \mathrm{~km}$ away from Irkutsk on the north-western coast of the southern basin of Lake Baikal. In recent years, the settlement of Listvyanka (5000 people) has become a tourist center at Lake Baikal, thus causing an increase of road transport on the relatively small isolated territory. In 2000, these sites were included in the International Program "Monitoring of Acid Deposition in East Asia (EANET)". Sampling and analyses of samples of atmospheric precipitation were performed according to recommended methods for the entire network of sites of this program [20] [21]. Rain was collected with an automatic "wet-only" sampler "US-320" (Japan). We used plastic containers for sampling snow.

In 2010-2014, approximately 600 samples of atmospheric precipitation were 
analyzed for heavy metals, major anions and $\mathrm{pH}$. Samples of rain and snow water were filtered through membrane filters of $0.45 \mu \mathrm{m}$. Concentrations of heavy metals were measured in the dissolved fraction using inductively coupled plasma mass spectrometry on a spectrometer “Agilent-7500ce". Anions were studied using high-performance liquid chromatography on a chromatograph "Milichrom A-02". The measurement accuracy of concentrations of heavy metals and major anions were regularly controlled by annual inter-laboratory calibrations within the framework of international programs NIVA [22], EMEP [23], EANET [24], and WMO [25].

\section{Results and Discussion}

As is known, chemical composition of atmospheric precipitation is regulated by meteorological, climatic, seasonal and other factors affected by both natural processes and human activity.

Humid air masses penetrate deep into the continent from the Atlantic. Regeneration of cyclones above large industrial regions can be one of the circulation mechanisms of this effect, due to which they stay longer and are transported to East Siberia more intensely [26] [27]. In winter, north-eastern anticyclonic circulation prevails above the territory of Pribaikalye, whereas western circulation dominates in spring. A typical form of circulation in summer is central, when there is a weak gradient of low pressure near the surface. Cyclones are directed from west to east accompanying by anticyclone intrusions [28].

Average annual concentrations of heavy metals measured in atmospheric precipitation at monitoring sites (Irkutsk and Listvyanka) in Pribaikalye were compared with those obtained at three EMEP monitoring sites [29] (Table 1). European sites were chosen on the basis of comparable amount of precipitation at sites Irkutsk and Listvyanka. Concentrations of heavy metals in atmospheric precipitation were higher at sites in Pribaikalye than in Europe, some of them being one order of magnitude higher.

Hence, the content of heavy metals at monitoring sites of Europe and Pribaikalye can be compared only in case when atmospheric precipitation forms under

Table 1. Average annual concentrations of heavy metals in atmospheric precipitation at European monitoring sites in 2007 [29] and Pribaikalye in 2012, $\mu \mathrm{g} / \mathrm{L}^{-1}$.

\begin{tabular}{|c|c|c|c|c|c|c|c|c|c|c|c|c|}
\hline \multirow{2}{*}{$\begin{array}{l}\text { Monitoring } \\
\text { site }\end{array}$} & \multirow{2}{*}{$\begin{array}{c}\text { Amount of } \\
\text { precipitation, } \\
\mathrm{mm}\end{array}$} & \multicolumn{11}{|c|}{ Element } \\
\hline & & $\mathrm{V}$ & $\mathrm{Cr}$ & $\mathrm{Mn}$ & $\mathrm{Fe}$ & Co & $\mathrm{Ni}$ & $\mathrm{Cu}$ & $\mathrm{Zn}$ & $\mathrm{Cd}$ & As & $\mathrm{Pb}$ \\
\hline $\begin{array}{c}\text { Germany } \\
\text { (Zingst) }\end{array}$ & 771 & 0.38 & 0.13 & 2.34 & 14 & 0.02 & 0.29 & 2.13 & 7 & 0.03 & 0.08 & 0.81 \\
\hline $\begin{array}{c}\text { Finland } \\
\text { (Hailuoto) }\end{array}$ & 452 & 0.43 & 0.16 & 2.03 & 25 & 0.04 & 0.17 & 1.93 & 3 & 0.03 & 0.04 & 0.66 \\
\hline Sweden (Arup) & 1049 & 0.64 & 0.13 & 4.07 & - & 0.02 & 0.28 & 0.79 & 8 & 0.03 & 0.14 & 0.47 \\
\hline Russia (Irkutsk) & 480 & 1.33 & 0.84 & 20.6 & 39 & 0.38 & 1.54 & 4.55 & 23.3 & 0.26 & 0.14 & 0.52 \\
\hline $\begin{array}{c}\text { Russia } \\
\text { (Listvyanka) }\end{array}$ & 430 & 0.76 & 0.66 & 11.5 & 30 & 0.29 & 1.81 & 3.66 & 29.4 & 0.22 & 0.09 & 1.01 \\
\hline
\end{tabular}


the influence of natural factors. However, we observe rather high concentrations of heavy metals at site Listvyanka and even higher at site Irkutsk, which is likely caused by the impact of other factors on chemical composition of precipitation, including anthropogenic ones.

The main source of atmosphere pollution in Pribaikalye is Irkutsk-Cheremkhovo industrial complex, which includes enterprises of heat and power engineering, nonferrous metallurgy, chemical, pulp-and-paper industry, construction materials, road and railway transport and others. Because of prevailing north-western transport of air masses in this region, impurities emitted into atmosphere are transported from cities and towns, including Irkutsk, along the Angara River valley towards the coast and water area of Southern Baikal, where site Listvyanka is located. Another source of atmosphere pollution in Pribaikalye may be transport of air pollutants from the neighboring industrial region (Krasnoyarsk Krai) [30].

As was mentioned earlier, one of the main sources of emission of heavy metals into atmosphere is heat and power engineering. According to the EMEP report, the content of heavy metals in atmospheric precipitation significantly decreased from 1990 to 2011: lead by $90 \%$ and cadmium by $60 \%$ due to the complete substitution of coal by natural gas at the enterprises of heat and power engineering [31]. In Pribaikalye, the majority of enterprises of this industry work on solid fuel, which does not lead to the decrease of air emissions and, consequently content of heavy metals in atmospheric precipitation. Emissions from these enterprises are maximal in cold period, which lasts in Pribaikalye from November to April. Therefore, the highest concentration of heavy metals in precipitation is expected to be at this time. We studied seasonal dynamics of concentration of dissolved fraction of heavy metals in atmospheric precipitation in Pribaikalye (Figure 1 and Figure 2).

As is seen from these figures, no pronounced maximum of heavy metals was registered in winter period. During December-February, metals are emitted into atmosphere mainly with particulates. Therefore, they are in insoluble state. The exceptions are such elements as $\mathrm{V}$ and Co, whose concentrations are, on the contrary, maximal in winter. According to the data of National Atmospheric
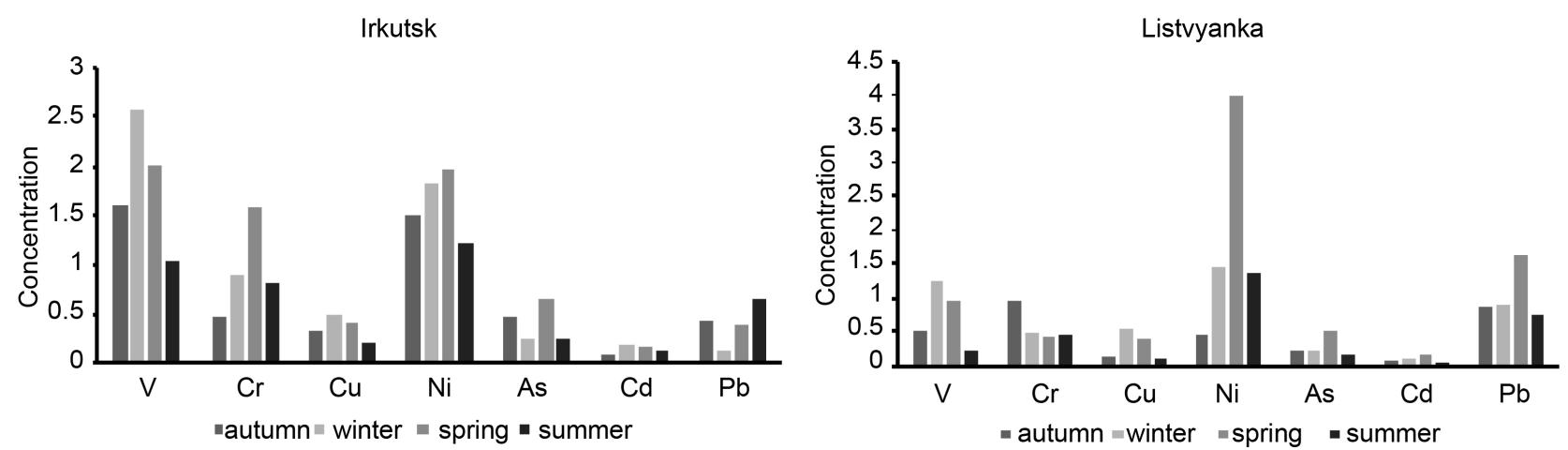

Figure 1. Seasonal dynamics in concentration of heavy metals in atmospheric precipitation at monitoring sites Irkutsk (left) and Listvyanka (right) in 2010-2014, $\mu \mathrm{g} \cdot \mathrm{L}^{-1}$. 
Irkutsk

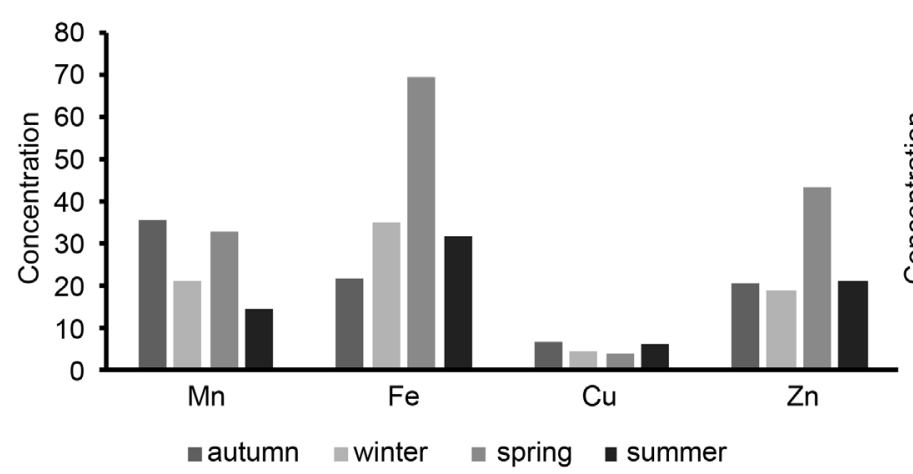

Listvyanka

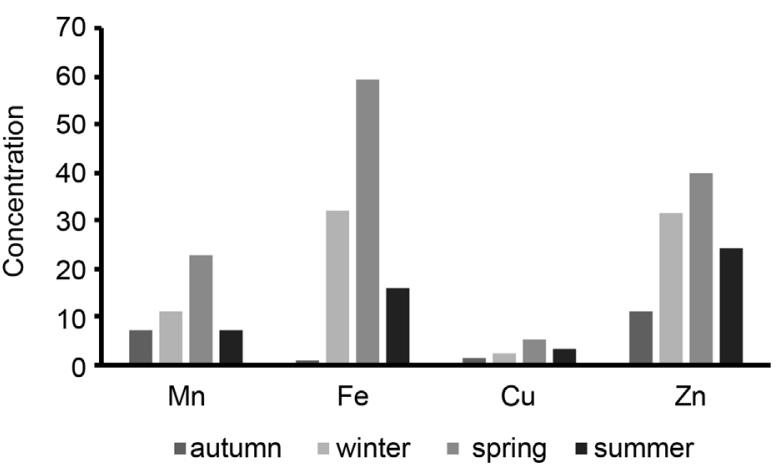

Figure 2. Seasonal dynamics in concentration of heavy metals in atmospheric precipitation at monitoring sites Irkutsk (left) and Listvyanka (right) in 2010-2014, $\mu \mathrm{g} \cdot \mathrm{L}^{-1}$.

Emission Inventory, motor fuel, mainly diesel, is $98 \%$ source of $\mathrm{V}$ emission [32]. Another source of vanadium is mazut, which is used in some boilers of Pribaikalye and, particularly in Listvyanka, where a monitoring site is located.

Maximal concentrations of the majority of metals were recorded in spring, as a rule, in dry period, which was attributed primarily to natural factors. In spring, the concentrations of aerosol of terrigenous origin increased after snow melting and with the rise of air temperature and increase of wind velocity in atmosphere of Pribaikalye. Forest fires, a powerful source of aerosol in the Siberian region, usually happen in this period.

Hence, despite significant variations of average monthly concentrations of heavy metals there was a trend in the within-year dynamics with spring maximum and summer-fall minimum for the majority of elements. Minimal content of heavy metals in atmospheric precipitation in summer-fall was attributed to purification of atmosphere from impurities due to high amount of precipitation (up to $70 \%$ of annual total), which is consistent with within-year dynamics of ionic composition of atmospheric precipitation. According to Netsvetaeva et al. 2013 [33], minimal concentrations of ions in atmospheric precipitation were recorded also in summer and fall months, whereas maximal values were registered in spring months of cold period (March-April). In the annual dynamics of metal concentrations, the drop from minimum to maximum in the majority of elements made up one-two orders of magnitude, whereas for $\mathrm{Cd}$ it was three orders of magnitude. The content, as a rule, sharply increased when the amount of atmospheric precipitation deposited after long dry period, when in atmosphere a large amount of impurities accumulated.

Long-term investigations showed that average annual concentrations of $\mathrm{Pb}, \mathrm{Ni}$ and $\mathrm{Zn}$ in atmospheric precipitation at site Listvyanka were higher than at site Irkutsk despite high anthropogenic load on the industrial center (see Table 1). The probable reason for such phenomenon could be deposition of acid precipitation at the rural site, thus increasing dissolution of metals. Average annual (1999-2014) $\mathrm{pH}$ value at site Listvyanka was 5.12 without significant seasonal differences in acidity of precipitation. The amount of acidic precipitation with 
$\mathrm{pH}$ lower than 5 reached $67 \%$ in certain years, whereas in Irkutsk did not exceed $20 \%$. In precipitations from the urban site with higher $\mathrm{pH}$ values (5.98 on average), the majority of metals were insoluble. Seasonal dynamics in the lead content in precipitation was of peculiar character at monitoring sites. As seen in Figure 1, seasonal trend of this component is typical in Listvyanka with its maximum in spring (soil erosion factor) and minimum in summer (maximal amount of precipitation). In Irkutsk, the highest concentrations of lead were recorded in summer and the lowest in winter. Summer maximum was attributed to high acidity of precipitation at site Irkutsk in this period. Average long-term $\mathrm{pH}$ value of rain was 5.52 at site Irkutsk. However, in some cases the $\mathrm{pH}$ values were lower than 4.0. In cold period, the $\mathrm{pH}$ value was much higher in Irkutsk (6.43 on average), reaching 8.40 in some cases. This was attributed to high volume of ash emissions from enterprises of heat and power engineering.

Similar dynamics was observed for $\mathrm{Ni}$ at site Listvyanka where its content was higher than in Irkutsk because of spring maximum (Figure 1). Concentrations of dissolved $\mathrm{Zn}$ at the rural site were almost 2 times higher in winter than in Irkutsk (Figure 2). During a year, the concentrations of heavy metals considerably vary. Figure 3 and Figure 4 represent variations in the heavy metal contents during a year.

As it is seen from Figure 3, the content of $\mathrm{V}$ is higher during winter months and attends its maximum in January at two sites: Irkutsk and Listvyanka. Cr concentration varies from 0.4 to $2.16 \mu \mathrm{g} \cdot \mathrm{L}^{-1}$ at Irkutsk site and from 0.18 to $1.9 \mu \mathrm{g} \cdot \mathrm{L}^{-1}$ at Listvyanka site, maximal concentrations are revealed in February and November.

Irkutsk

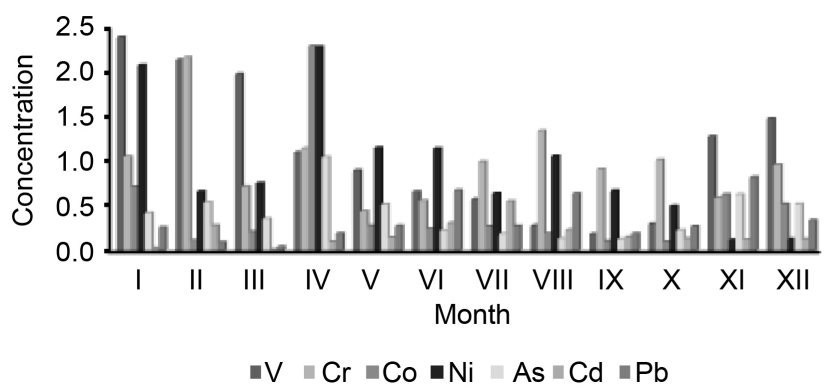

Listvyanka

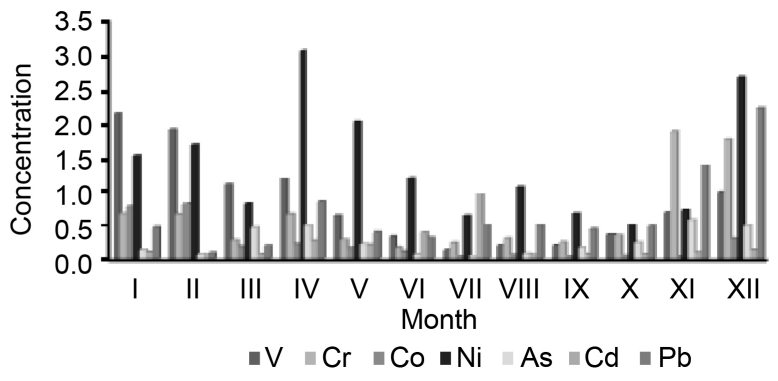

Figure 3. Heavy metals contents in precipitations during different months of a year in 2012-2014, $\mu \mathrm{g} \cdot \mathrm{L}^{-1}$.

Irkutsk

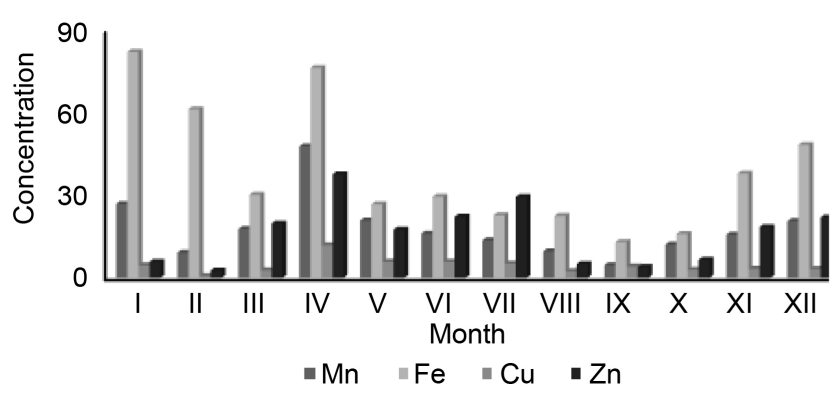

Listvyanka

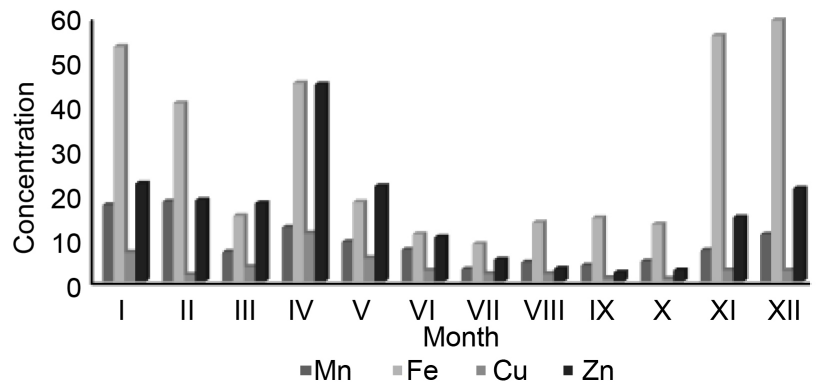

Figure 4. Heavy metals contents in precipitations during different months of a year in 2012-2014, $\mu \mathrm{g} \cdot \mathrm{L}^{-1}$. 
A minimal value for Co is revealed in September, and maximal one-in April for Irkutsk site. At Listvyanka site, minimal value is observed in October, and maximal one-in February. Ni content is maximal in April and minimal in October at both sites. Ascontent for Irkutsk site is maximal in April, and for Listvyanka site-in November. The only element which has maximal values during summer period is $\mathrm{Cd}$, its content is maximal in July at both monitoring sites. This is probably due to cyclones from Mongolia passing at that time over the region. $\mathrm{Pb}$ content is maximal in November at Irkutsk site and in December at Listvyanka site.

Such elements as $\mathrm{Fe}, \mathrm{Mn}, \mathrm{Cu}, \mathrm{Zn}$ have maximal values in April except Fe, its maximum for Irkutsk site takes place in January. For Listvyanka site, maximal content of $\mathrm{Mn}$ is in February, one of Fe is in December, and one of $\mathrm{Cu}$ and $\mathrm{Zn}$ is in April, like for Irkutsk site (Figure 4). Hence, distribution of heavy metals contents differs by months for two stations. This is due to precipitations amount: in summer, the precipitation amount is maximal, and minimal concentrations are observed. During winter and spring months, the concentrations level increases due to a high anthropogenic charge and to melting of snow cover at underlying surface (in spring).

Correlation coefficients were calculated for establishing interconnection between concentrations of major anions and $\mathrm{pH}$ and heavy metals in atmospheric precipitation (Table 2 and Table 3 ).

In Listvyanka, the majority of atmospheric precipitations were acidified to a certain degree. It was supposed that there would be good correlation between concentrations of heavy metals and $\mathrm{pH}$ value. However, the calculations showed opposite correlation. At site Listvyanka, the highest correlation coefficient was recorded only for lead (0.56).

Table 2. Correlation coefficients between anions, $\mathrm{pH}$ and heavy metals in atmospheric precipitation at site Irkutsk.

\begin{tabular}{cccccccccccc}
\hline Component & $\mathrm{V}$ & $\mathrm{Cr}$ & $\mathrm{Mn}$ & $\mathrm{Fe}$ & $\mathrm{Co}$ & $\mathrm{Ni}$ & $\mathrm{Cu}$ & $\mathrm{Zn}$ & $\mathrm{As}$ & $\mathrm{Cd}$ & $\mathrm{Pb}$ \\
\hline $\mathrm{HCO}_{3}^{-}$ & 0.68 & 0.08 & 0.43 & 0.25 & 0.20 & 0.20 & 0.42 & 0.07 & 0.47 & -0.06 & 0.09 \\
$\mathrm{SO}_{4}^{2-}$ & 0.52 & 0.35 & 0.69 & 0.39 & 0.41 & 0.28 & 0.51 & 0.26 & 0.46 & 0.10 & -0.06 \\
$\mathrm{NO}_{3}^{-}$ & 0.59 & 0.14 & 0.52 & 0.23 & 0.57 & 0.40 & 0.20 & 0.10 & 0.18 & 0.30 & -0.33 \\
$\mathrm{Cl}^{-}$ & 0.65 & 0.08 & 0.58 & 0.30 & 0.15 & 0.11 & 0.55 & 0.06 & 0.54 & 0 & 0.21 \\
$\mathrm{pH}$ & -0.45 & -0.11 & -0.27 & -0.12 & -0.39 & -0.34 & -0.09 & -0.13 & -0.19 & -0.17 & 0.70 \\
\hline
\end{tabular}

Table 3. Correlation coefficients between anions, $\mathrm{pH}$ and heavy metals in atmospheric precipitation at site Listvyanka.

\begin{tabular}{cccccccccccc}
\hline Component & $\mathrm{V}$ & $\mathrm{Cr}$ & $\mathrm{Mn}$ & $\mathrm{Fe}$ & $\mathrm{Co}$ & $\mathrm{Ni}$ & $\mathrm{Cu}$ & $\mathrm{Zn}$ & $\mathrm{As}$ & $\mathrm{Cd}$ & $\mathrm{Pb}$ \\
\hline $\mathrm{SO}_{4}^{2-}$ & 0.62 & -0.02 & 0.81 & 0.86 & 0.63 & 0.46 & 0.47 & -0.15 & 0.66 & 0.72 & 0.49 \\
$\mathrm{NO}_{3}^{-}$ & 0.83 & 0.14 & 0.57 & 0.67 & 0.98 & 0.23 & 0.17 & -0.11 & 0.25 & 0.50 & 0.13 \\
$\mathrm{Cl}^{-}$ & 0.48 & 0.25 & 0.68 & 0.68 & 0.45 & 0.26 & 0.38 & -0.04 & 0.74 & 0.50 & 0.27 \\
$\mathrm{pH}$ & -0.30 & -0.18 & -0.11 & -0.08 & -0.39 & -0.01 & 0.26 & -0.29 & -0.21 & -0.19 & 0.56 \\
\hline
\end{tabular}


In recent years, the rise of acidity of atmospheric precipitation has been registered in Pribaikalye [33] [34] due to the increase of anthropogenic emission of sulfur and nitrogen oxides in this region. Acidity of atmospheric precipitation increased in summer in the absence of neutralizing alkaline components. Nitrate and sulfate contributed equally to acidity of atmospheric precipitation. This is consistent with the data on several heavy metals. The latter correlated with major acid-forming anions. For example, stable correlation was recorded between $\mathrm{SO}_{4}^{2-}$ and $\mathrm{Mn}, \mathrm{V}$ and $\mathrm{Cu}$ at site Irkutsk, whereas $\mathrm{NO}_{3}^{-}$was correlated, to a greater extent, with $\mathrm{V}$, Co and $\mathrm{Mn}$. The correlation was observed between $\mathrm{Cl}^{-}$ and $\mathrm{V}, \mathrm{Mn}, \mathrm{Cu}$ and As. Like in Listvyanka, significant correlation was recorded between lead and $\mathrm{pH}$ value (Table 2).

At site Listvyanka, correlation coefficients were higher. Anions correlated with a higher number of elements (Table 3 ). $\mathrm{SO}_{4}^{2-}$ correlated well with $\mathrm{V}, \mathrm{Mn}$, $\mathrm{Fe}$, Co and As. Co had the highest correlation coefficient with $\mathrm{NO}_{3}^{-}$. Unlike Irkutsk site, high correlation was recorded between $\mathrm{SO}_{4}^{2-}, \mathrm{Cd}$ and As at site Listvyanka.

Thus, the investigations performed confirm that in the regions of Pribaikalye remote from industrial centers, solubility of heavy metals increased because of acidification of atmospheric precipitation. High concentrations of heavy metals in atmospheric precipitation can negatively affect the natural environment causing inhibition of forests, increase of areas of necrosis of needles and leaves and decrease of their mass [35] [36].

\section{Conclusions}

In 2010-2014, investigations of the content of heavy metals in atmospheric precipitation, their emission into atmosphere and seasonal dynamics were performed at two monitoring sites in Pribaikalye. The main sources of emission of heavy metals into atmosphere are eolian transport from the underlying surface, enterprises of heat and power engineering, forest fires and road transport. Maximal concentrations of the majority of elements were recorded in spring in a drier period of the year, whereas minimal content was registered in summer, when the amount of precipitation in this region was maximal.

The results obtained show higher level of pollution of atmospheric precipitation by heavy metals at monitoring sites in Pribaikalye compared to some European countries. High correlation was established V and $\mathrm{Mn}$ with major acid-forming anions $\mathrm{SO}_{4}^{2-}$ and $\mathrm{NO}_{3}^{-}$. Maximal correlation coefficient (0.98) was recorded for Co and $\mathrm{NO}_{3}^{-}$at site Listvyanka. Unlike site Irkutsk, significant correlation coefficients were also recorded for $\mathrm{Fe}$, As and Cd at site Listvyanka. No correlation was registered between $\mathrm{pH}$ of atmospheric precipitation and concentrations of all heavy metals, except $\mathrm{Pb}$.

\section{Acknowledgements}

The work was supported by the program 0345-2016-0008 "Assessment and Forecast of Ecological State of Lake Baikal and Adjacent Territories under Con- 
ditions of Anthropogenic Impact and Climate Changes".

\section{References}

[1] Nriagu, J.O. and Pacyna, J.M. (1988) Quantitative Assessment of Worldwide Contamination of Air, Water and Soils by Trace Metals. Nature, 333, 134-139. https://doi.org/10.1038/333134a0

[2] Pacyna, E.G. and Pacyna, J.M. (2002) Global Emission of Mercury from Anthropogenic Sources in 1995. Water, Air, and Soil Pollution, 137, 143-165. https://doi.org/10.1023/A:1015502430561

[3] Kleeman, M.J., Riddle, S.G., Robert, M.A. and Jakober, C.A. (2008) Lubricating oil and Fuel Contributions to Particulate Matter Emissions from Light-Duty Gasoline and Heavy-Duty Diesel Vehicles. Environmental Science \& Technology, 42, 235242. https://doi.org/10.1021/es071054c

[4] Wiseman, C.L. and Zereini, F. (2009) Airborne Particulate Matter, Platinum Group Elements and Human Health: A Review of Recent Evidence. Science of the Total Environment, 407, 2493-2500. https://doi.org/10.1016/j.scitotenv.2008.12.057

[5] Dubiella-Jackowska, A., Polkowska, Z. and Namiennik, J. (2009) Platinum Group Elements in the Environment: Emissions and Exposure. Reviews of Environmental Contamination and Toxicology, 199, 111-135.

[6] Spada, N., Bozlaker, A. and Chellam, S. (2012) Multi-Elemental Characterization of Tunnel and Road Dusts in Houston, Texas Using Dynamic Reaction Cell-Quadrupled-Inductively Coupled Plasma-Mass Spectrometry: Evidence for the Release of Platinum Group and Anthropogenic Metals from Motor Vehicles. Analytica Chimica Acta, 735, 1-8. https://doi.org/10.1016/j.aca.2012.05.026

[7] Saet, Y.E., Revich, B.A. and Yanin, E.P. (1990) Geokhimiya okruzhayuschei sredi. Nedra, Moskva.

[8] Dabakhov, M.V., Dabakhova, E.V. and Titova, V.I. (2005) Ekotoksikologiya i problemi standartizatsii. Nizhegorodskaya Gosudarstvennaya Selskokhozyaistvennaya Akademiya. VVAGS, N. Novgorod.

[9] Berg, T., Aas, W., Pacyna, J., Uggerud, H.T. and Vadset, M. (2008) Atmospheric Trace Metal Concentrations at Norwegian Background Sites during 25 Years and Its Relation to European Emissions. Atmospheric Environment, 42, 7494-7501. https://doi.org/10.1016/j.atmosenv.2008.05.020

[10] Kummer, U., Pacyna, J., Pacyna, E. and Friedrich, R. (2009) Assessment of Heavy Metal Releases from the Use Phase of Road Transport in Europe. Atmospheric Environment, 43, 640-647. https://doi.org/10.1016/j.atmosenv.2008.10.007

[11] Bacardit, M. and Camarero, L. (2010) Atmospherically Deposited Major and Trace Elements in the Winter Snowpack along a Gradient of Altitude in the Central Pyrenees: The Seasonal Record of Long-Range Fluxes over SW Europe. Atmospheric Environment, 44, 582-595. https://doi.org/10.1016/j.atmosenv.2009.06.022

[12] Connan, O., Maro, D., Hebert, D., Roupsard, P., Goujon, R., Letellier, B. and Le Cavelier, S. (2013) Wet and Dry Deposition of Particles Associated Metals (Cd, Pb, $\mathrm{Zn}, \mathrm{Ni}, \mathrm{Hg}$ ) in a Rural Wetland Site, Marais Vernier, France. Atmospheric Environment, 67, 394-403. https://doi.org/10.1016/j.atmosenv.2012.11.029

[13] Obzor fonovogo sostoyaniya okruzhayuschey sredi na territorii stran Soyuza Nezavisimikh Gosudarstv v 2013 (2014) Institut Globalnogo Klimatai Ekologii Rosgidrometi Rossiyskoy Akademii Nauk, Moskva.

[14] Obzor zagryazneniya i sostoyaniya okruzhayuschey sredi v Rossiyskoy Federatsii v 2014 (2015) Institut Globalnogo Klimatai Ekologii Rosgidrometi Rossiyskoy Aka- 
demiiNauk, Moskva.

[15] Ezhegodnik. Sostoyaniye zagryazneniya atmosfery v gorodakh na territorii Rossii v 2014 (2015) Rosgidromet, Voeikov, A.I. Glavnaya Geofizicheskaya Observatoriya, Sankt-Peterburg.

[16] Gadaskina, I.D. and Tolokontsev, N.A. (1988) Yadi vchera i segodnya: Ocherki po istorii yadov. Nauka, Leningrad.

[17] Ecologicheskie problemi promishlennih gorodov (2011) Sbornik nauchnih trudov, Chast 1, Saratovskiy Gosudarstvenniy Tehnicheskiy Universitet, Saratov.

[18] Kargin, I.F. and Igonov, I.I. (2013) Khimicheskiy sostav atmosfernih osadkov i soderzhaniye v nikhtyazhelih metallov. Russian Scientific World, 1, 49-55.

[19] Korobka, O.V., Ovcharenko, E.A., Eirikh, A.N., Serykh, T.G., Dryupina, E.Yu. and Papina, T.S. (2014) Khimicheskiy sostav atmosfernih osadkov goroda Barnaula. Polzunovskiy Vestnik, 4, 80-83.

[20] Guidelines for Acid Deposition Monitoring in East Asia (2000) 2nd Interim Scientific Advisory Group Meeting, ADORC Press, Niigata.

[21] Network Center (2010) Technical Manual for Wet Deposition Monitoring in East Asia. Network Center for EANET Press, Niigata.

[22] http://kvina.niva.no/intercomparison

[23] http://www.nilu.no

[24] http://www.acap.asia/ interlab/os

[25] http://www.qasac-americas.org

[26] Izrael, Yu.A., Gruza, V.G., Katsov, V.M. and Meleshko, V.P. (2001) Global Climate Changes. Role of Anthropogenic Impacts. Izhmeneniye globalnogo klimata. Rol antropogennikh vozdeystviy. Meteorologiyai Gidrologiya, 14, 5-21.

[27] Vinogradova, A.A., Maksimenkov, L.O. and Pogarsky, F.A. (2009) Change of Atmospheric Circulation and Pollution of Environment in Siberia by Industrial Areas of Norilsk and Urals in the Early XXI Century. Izmeneniye atmosfernoy tsirkulyatsii i zagryazneniya okruzhayuschey sredi v Sibiri ot promishlennih rayonov Norilska i Urala v nachale XXI v. Optika Atmosfery i Okeana, 22, 527-534.

[28] Latysheva, I.V., Ivanova, A.S., Makukhin, V.L. and Mordvinov, V.I. (2004) Air synoptical Features of Southern Cyclones Coming onto Pribaikalye and Their Influence on the Lake Baikal Area. The International Society for Optical Engineering, 5743, 601-605.

[29] EMEP/CCC (2009) Manual for Sampling and chemical Analysis. EMEP Cooperative Program for Monitoring and Heavy Metals and POP Measurements, NILU: EMEP/CCC.

[30] Chipanina-Molozhnikova, E.V., Golobokova, L.P., Kuchmenko, E.V., Netsvetaeva, O.G. and Khodzher, T.V. (2007) Conditions for Formation of Chemical Composition of Atmospheric Aerosol and Precipitation over the Baikal Natural Territory. Usloviya formirovaniya himicheskogo sostava atmosfernogo aerosolya i osadkov nad Baikalskoy Prirodnoy Territoriey. Optika Atmosfery i Okeana, 20, 900-905.

[31] EMEP/CCC (2012) Long-Term Changes of Heavy Metal Transboundary Pollution of the Environment (19902010). NILU: EMEP/CCC.

[32] Concowe, R. (1999) Emission Inventory Guidebook. RoadTransport, London.

[33] Netsvetaeva, O.G., Chipanina, E.V., Obolkin, V.A., Zimnik, E.A., Sezko, N.P., Lopatina, I.N. and Khodzher, T.V. (2013) Peculiarities of Chemistry of Atmospheric Precipitation at Stations Listvyanka (Irkutsk Region) and Primorskaya (Primorye Territory). Osobennosti himii atmosfernih osadkov stantsiy Listvyanka (Irkutskaya 
oblast) iPrimorskaya (Primorskiy kray).Optika Atmosfery i Okeana, 26, 466-471.

[34] Obolkin, V.A., Netsvetaeva, O.G., Golobokova, L.P., Potemkin, V.L., Zimnik, E.A., Filippova, U.G. and Khodzher, T.V. (2013) Results of Long-Term Investigations on Acid Deposition in Southern Baikal. Rezultati mnogoletnih issledovaniy kislotnikh vipadeniy v rayone Yuzhnogo Baykala. Geografiyai Prirodniye Resursi, 2, 66-73.

[35] Mikhailova, T.A. (2003) Vliyaniye promishlennih vibrosov na lesa Baikalskoy Prirodnoyterritorii. Geografiyai Prirodniye Resursy, 1, 51-58.

[36] Shergina, O.V. and Mikhailova, T.A. (2007) Sostoyaniye drevesnih rasteniy i pochvennogo pokrovaparkovih i lesoparkovikh zon Irkutska. Institut Geographii SO RAN, Irkutsk.

Submit or recommend next manuscript to SCIRP and we will provide best service for you:

Accepting pre-submission inquiries through Email, Facebook, LinkedIn, Twitter, etc. A wide selection of journals (inclusive of 9 subjects, more than 200 journals)

Providing 24-hour high-quality service

User-friendly online submission system

Fair and swift peer-review system

Efficient typesetting and proofreading procedure

Display of the result of downloads and visits, as well as the number of cited articles

Maximum dissemination of your research work

Submit your manuscript at: http://papersubmission.scirp.org/

Or contact ajcc@scirp.org 